\title{
Career Choice Motivations of University Students
}

\author{
Heiko Haase \\ Department of Business Administration, University of Applied Sciences Jena \\ Carl-Zeiss-Promenade 2, 07745 Jena, Germany \\ Tel: +49-3641-205573Ｆax: +49-3641-205551Ｅ-mail: heiko.haase@fh-jena.de \\ Arndt Lautenschläger (Corresponding author) \\ Department of Business Administration, University of Applied Sciences Jena \\ Carl-Zeiss-Promenade 2, 07745 Jena, Germany \\ Tel: +49-3641-205591Ｆax: +49-3641-205594Ｅ-mail: arndt.lautenschlaeger@fh-jena.de
}

Received: November 1, $2010 \quad$ Accepted: December 7, $2010 \quad$ doi:10.5430/ijba.v2n1p2

\begin{abstract}
In view of the universities' role as a source of qualified labour, the paper aims at exploring what motivations determine students' career choice. Therefore, we performed a cross-sectional study of the underlying motives for the career intentions of 645 students from two German universities. The findings reveal that the motives can be grouped and systemised into the main components 'Status orientation', 'Self-realisation' and 'Self-determination'. In our sample, these categories and the underlying motives are to a certain extent relevant for self-employment, but less for dependent employment alternatives. In particular, 'Self-determination' was found to be inherent for any type of self-employment.
\end{abstract}

Keywords: Career choice, Motivation, Student survey, Germany.

\section{Introduction}

In today's world, higher education institutions play an ever-increasing role. Besides their traditional functions of teaching and research, they are now challenged to contribute to society's economic and social development, which is often articulated as relevance or the 'third mission' of universities (Gibb, 1996; Johannisson, Handström, \& Rosenberg, 1998; Etzkowitz, Webster, Gebhardt, \& Terra, 2000). How universities could contribute to economic progress and structural change is illustrated by the impressive examples of Massachusetts Institute of Technology and other universities (Chrisman, Hynes, \& Fraser, 1995; Hsu, Roberts, \& Eesley, 2007; Bramwell \& Wolfe, 2008). Hereby, 'producing' qualified people is an important task and perhaps the most fruitful transfer mechanism.

In this context, the universities' relevance is twofold. On the one hand, the constantly regenerating stock of students and scientists stand for an enormous potential of ideas for creating new business ventures. Studies have shown that individuals with a university degree have a higher proclivity to start their own business (Sternberg et al., 2007). Furthermore, firms issuing from the academic environment have a particular potential for growth and innovation (Roberts, 1991; Steffensen, Rogers, \& Speakman, 2000). Therefore, economic policy makers claim the promotion of start-ups from the higher education sector. The last decades have witnessed an immense growth in establishing entrepreneurship as an academic discipline and instituting entrepreneurship courses and programmes at all educational levels (Falkäng \& Alberti, 2000; Hisrich, 2003; Solomon, Duffy, \& Tarabishy, 2002). However, when business creation by graduates is intended, it is imperative to understand the motives of those who strive for self-employment in order to sensitise and educate them accordingly.

On the other hand and apart from the fact that only a certain percentage of individuals are likely to start a new business, it is important to know to which extent qualified people pursue some specific types of professional activities. For example, new and growing firms cannot make progress if they do not have competent people willing to work in these businesses. From this point of view, it is equally appropriate to inspire students to ponder the option of employment in new and growing firms (Lautenschläger \& Haase, 2010). In general, if the overall goal is to increase economic activity, human resources must be efficiently allocated. For this purpose again, there is a need to anticipate students' career choices and the underlying motivations. The rationale of our research is that comprehending the students' motives for career choice is crucial not only for entrepreneurship education and graduate entrepreneurship. It is also highly relevant for the universities' socio-economic role in general. 
Motives and reasons for self-employment have been extensively researched. Yet, there is a void in literature regarding their differentiation according to the various types of self-employment (e.g. starting a business, taking over a business, working as freelancer). Moreover, the analysis of other career choices (e.g. being employed in a small or medium-sized firm, large company, public service) are almost absent from scientific scrutiny. Consequently, the present paper pursues the central research question: What career intentions do university students have and what are the underlying motives? In order to tackle this subject, this cross-sectional study explores the motives for the career choice of university students from Eastern and Western German higher education institutions. In this way, in terms of theoretical contribution, we try to better understand and to enhance the knowledge in explaining the career decisions of university students.

The remainder of the paper is structured as follows: In Section 2, we present theory about motives for career choice. Section 3 contains the research methodology, i.e. data, sample, variables and statistical analyses. Thereafter, Section 4 presents the results of our survey and discusses the findings. Section 5 finishes with a conclusion as well as implications and limitations of our study.

\section{Literature Review}

\subsection{Motives for Career Choice}

Several prior studies have found that career choices are determined by many, sometimes quite different motives. In this context, some theories for understanding the reasons underlying the decision to begin a specific occupational or entrepreneurial career have been developed over time. As a result, the Theory of Social Learning (Bandura, 1977), the Entrepreneurial Event Theory (Shapero \& Sokol, 1982) and the Theory of Planned Behaviour (Ajzen, 1991) have emerged as the most promising approaches. The central element of these theories is the individual's intention to undertake and to put a specific behaviour into practice, influenced by motivational elements. In general, the motives can be classified into cognitive personal factors on the one hand; contextual or environmental factors on the other. They can exert positive or negative influence on the intended career, and often their specific combination and interaction moulds the individual's decision to enter a particular career path.

\subsection{Cognitive Factors}

With regard to the cognitive factors, most of the research conducted has centred around the question "what motivates people to step into self-employment?". Among the motives most cited, scholars found self-realisation (Gatewood, Shaver, \& Gartner, 1995; Kolvereid, 1996; Carter, Gartner, Shaver, \& Gatewood, 2003), need of autonomy and independence (Brockhaus, 1980; Carter et al., 2003; Van Auken, Stephens, Fry, \& Silva, 2006; Kuratko, Hornsby, \& Naffziger, 1997; Douglas \& Shepherd, 2002), social recognition and status (Shane, Kolvereid, \& Westhead, 1991; Birley \& Westhead, 1994; Carter et al., 2003; Nelson, 1968; Scheinberg \& MacMillan, 1988), the propensity to take risks (Koh, 1995; Van Auken et al., 2006) as well as learning, gaining experience and need for personal development (Birley \& Westhead, 1994; Gatewood et al., 1995; Scheinberg \& MacMillan, 1988; Lautenschläger \& Haase, 2010). Furthermore, quite a number of researchers highlight financial success and high income (Evans \& Leighton, 1989; Shane et al., 1991; Carter et al., 2003; Kuratko et al., 1997; Douglas \& Shepherd, 2002). Nevertheless, it seems that economic motives are considered less important than other objectives (Baumol, 1993).

Exploring the weighting of the motives behind self-employment in the German context, the most comprehensive study was performed by Josten et al. (2008). These scholars surveyed more than 15,000 students at 37 German higher education institutions, and found that the most important drivers are working under one's own initiative (90.0\%), making better use of one's own capabilities (81.2\%), self deciding on working hours and place (79.8\%), being one's own boss (76.4\%) and realising one's own business or product ideas $(74.0 \%)$. Interestingly, in their study the chance of higher income (55.9\%) was ranked less essential. Lautenschläger and Haase (2010), in a holistic approach considering several career alternatives, investigated the prospective career paths of nearly 1,600 German undergraduate students. The findings revealed the predominance of two major motives: an assured position $(59.0 \%)$ and to gain experiences $(58.9 \%)$. Thereafter with less frequency, promotion prospects $(40.6 \%)$ and self-realisation $(40.3 \%)$ were cited by the respondents. Again, a high income was not important for the individuals in their sample (27.3\%), and social recognition (12.3\%) received almost no approval.

\subsection{Contextual Factors}

Concerning environmental or contextual factors (of cultural, social, political and economic nature) as determinants of career choice, only a few aspects have been scrutinised to date. The most relevant influence seems to be the perceived social pressure from family, friends or significant other 'people of reference' (Ajzen, 1991). Previous studies have shown that role models influence career choice; they particularly appear to encourage entrepreneurial careers (Krueger Jr., Reilly, \& Carsrud, 2000). Several scholars have shown the influence of parents' professional activities on children's career decisions, as they often prefer to work in the same field as their parents (Duchesneau \& Gartner, 1990; Scherer, 
Brodzinski, \& Wiebe, 1991). Hence, having an entrepreneurial family background points towards a higher likelihood for self-employment (Scott \& Twomey, 1988; Scherer, Adams, Carley, \& Wiebe, 1989; Koh, 1995; Tackey \& Perryman, 1999; Jacobsen, 2006).

Furthermore, the economic situation, especially the conditions in the labour market and the stability of employment appear to impact career choices (KFW Bankengruppe, 2005). In addition, the attractiveness of firm size determines potential career paths. For example, students may not be particularly attracted to work for a small firm due to lower wages, job security, career and training opportunities as well as other social contributions (Polachek \& Siebert, 1993; Miller \& Mulvey, 1996; Kalleberg \& Buren, 1996; Wagner, 1997). As a consequence, they disproportionately seek employement in larger or established companies (Bannock \& Daly, 1994; Belfield, 1999; Golla, Halter, Fueglistaller, \& Klandt, 2006).

\subsection{Research Hypotheses}

Based on this review of literature, Table 1 recapitulates the main motives for career choice, which we identified in the literature, separated into cognitive and contextual factors.

$<$ Table 1 about here $>$

From the number of factors, we extracted ten which we believe summarise and cover the variety we identified in the literature:

- The chance of higher income

- Prestige and social status

- Working under one's own initiative

- Realising one's own business or product ideas

- Making better use of one's own capabilities

- Fun when dealing with opportunities and risks

- Being one's own boss

- Self deciding on working hours and place

- The current situation in the labour market

- Continuation of family tradition

In line with our research question, we are now able to formulate the following set of hypotheses:

Hypothesis 1: Motives describing the desire for prestige, status and high income are interlinked with the intention to become employed in a large company. We believe that large companies are often able to provide better career options and wages compared to their smaller counterparts. The empirical evidence discussed in the former section underpins this assumption.

Hypothesis 2: Motives that imply the aspiration to be independent and to self-decide in planning professional activities are more inherent in individuals who strive for becoming self-employed. This assumption arises from the bulk of studies previously undertaken highlighting the importance of independence and autonomy as triggers for self-employment.

Hypothesis 3: Motives such as the wish to develop and implement new ideas correlate with the intention to start a new business. As new firms are often based on new or improved ideas, we think that graduates who plan to start a business are characterised by creativity and the stimulation to realise their own ideas in products or services.

\section{Methodology}

\subsection{Data and Sample}

To answer our research question, we carried out a cross-sectional study, aimed at surveying a population of undergraduate students at University of Applied Sciences Jena and Worms University of Applied Sciences. Jena, located in Eastern Germany, has been affected by radical structural changes since the Reunification of Germany. While traditional industries and large companies have collapsed, many innovative small and medium-sized firms have been established over the past twenty years. Worms, situated in Western Germany, is surrounded by prosperous chemical and synthetic as well as manufacturing industries, with the growing importance of services and trade. Thus, selection of these universities is due to the fact that they can be found in areas representing completely different cultural and economic realities.

The survey was conducted from November 2008 to February 2009. The questionnaires were firstly pre-tested using 20 graduating students in Jena and Worms. Thereafter, students from all sections of the two universities were approached by 
the interviewers. With the approval and cooperation of the lecturers, the interviewers distributed the questionnaires during the class sessions. This procedure ensured a weighted inclusion of students with different course backgrounds and years of study. The questionnaire encompassed various groups of questions related to the respondent's profile, demographic characteristics, motives for career choice as well as several career alternatives. We asked the students to indicate their career intentions shorty after completion of their studies and five years after graduation. In this way, the research was based on a prospective basis. A total of 645 undergraduate students participated in this study, making up our sample. This corresponds to almost $9 \%$ of the overall population of the two higher education institutions surveyed.

\subsection{Variables}

We used the following set of variables for our statistical analyses:

Dependent variables: Career choice were measured based on seven alternatives: (1) employed in a small-sized firm, (2) employed in a medium-sized firm, (3) employed in a large company, (4) employed in the public service, (5) self-employed as freelancer, (6) self-employed by business take-over and (7) self-employed by starting a business. By selecting these alternatives, we allowed the respondents to give a maximum of two multiple answers. The career intentions directly after graduation were specified as ' $t 0$ ', five years after completing the studies as ' $t 5$ '. For the analyses, we conceived each of the career alternatives as a dichotomous variable.

Independent variables: We constructed two models. Model 1 uses ten individual motives for career choice taken from our literature review (cf. Section 2.4). The majority of these motives were already tested for their operationability by Josten et al. (2008). Their importance was gathered through the five-point Likert scales, ranging from 1 for 'not important at all' to 5 for 'very important'. Again, Model 2 considers factors that are computed by a principal component analysis, indicating clusters of motives for career choice as independent variables.

Control variables: We controlled for gender, age, subject of study, the participation in entrepreneurship education and university location.

\subsection{Statistical Analyses}

The data analyses were done using descriptive statistics, principal component and logistic regression analyses. At this, the distinct motives for career choice were characterised through principal component analysis. Therefore, we applied varimax orthogonal rotation method, developed by Kaiser (1958). Based on this type of multivariate statistical analysis, the broad set of motives was reduced and grouped into some dimensions (factors) that are likely to be explanatory (Hair, Black, \& Babin, 2005). The first factor emerging from the application of this method explains the greatest percentage of the total sample variance. The second factor corresponds to the second biggest percentage of the total variance and so on. Principal components with Eigenvalues greater than one are usually retained. Items with a factor loading lower than 0.4 were removed. To check acceptability of the technique and determine the consistency of the components, the Kaiser-Meyer-Olkin measure (KMO) and the likelihood ratio test (LR test) were taken into consideration.

After clustering the motives for career choice according to the related significant factors, we applied logistic regression analysis (logit model). Based on this type of multivariate statistical analysis, we explored the relative weights of each variable and their level of significance. Hereby, the different career alternatives were related with the underlying motives (Model 1) and with the factors identified by principal component analysis (Model 2). In doing so, we distinguished between the coefficients for different employment and self-employment modes, both for ' $t 0$ ' and for ' $t 5$ '. For the estimation process, we applied STATA software.

\section{Findings and Discussion}

\subsection{Descriptive Statistics}

The descriptive results regarding the career choice as well as the socio-demographic and regional aspects are presented in Table 2. For the career intentions after graduation, most students surveyed prefer the following modes of employment: 'Medium-sized firm' (31.8\%), followed by 'Large company' (29.3\%) and 'Small-sized firm' (12.4\%). On the other hand, among the self-employment alternatives, we revealed that 'Starting a business' (2.3\%), 'Working as freelancer' $(2.5 \%)$ and 'Business take-over' (2.9\%) were ranked relatively low on the students' future job preferences.

\section{$<$ Table 2 about here $>$}

To analyse the career choices of students, a number of previous studies have been carried out in different countries (Chlosta, Klandt, \& Johann, 2006; Tackey \& Perryman, 1999; Greene \& Saridakis, 2008; Fueglistaller, Klandt, \& Halter, 2006). For example, Chlosta et al. (2006) asked students from different German universities and found on average that students intend to enter the job market after graduation as follows: large company (21.2\%), medium-sized company $(16.2 \%)$, small company (11.5\%) or self-employed (8\%). These insights are mainly in line with our findings; however, in our sample the large share of students willing to be employed in a medium-sized firm is outstanding. 
Five years after completing their studies, respondents ranked their career intentions concerning the modes of dependent employment distinctly: 'Large company' (37.8\%), followed by 'Medium-sized firm' (19.7\%) and 'Small-sized firm' $(6.8 \%)$. These numbers indicate a trend towards an employment in larger firms after some years of working experience. At least in the medium term, our results confirm studies (Bannock \& Daly, 1994; Belfield, 1999; Golla et al., 2006), which state that a considerable share of graduates are employed in larger companies.

Interestingly, in the medium term, the self-employment alternatives increased their attractiveness noticeably: 'Starting a business' (18.8\%), 'Working as freelancer' $(9.0 \%)$ and 'Business take-over' $(7.6 \%)$. Therefore, we identify a clear tendency for self-employment five years after graduation. This observation can be based on the fact that right after their studies, students usually do not have enough professional experiences and networks, which are key determinants to successfully run a business. Several scholars (Blanchflower \& Meyer, 1994; Golla et al., 2006) identified a positive correlation between professional know-how and the probability of founding a firm. Again, Wagner (2004) speaks of the 'Employer-as-a-role-model', which assumes that the work experience may facilitate employees the step into self-employment some years later.

The analysis of motives for career choice is based on their mean importance, as shown in the first column of Table 3. Hereby, the findings reveal that motives such as 'Working under one's initiative', 'The chance of higher income' and 'Making better use of one's own capabilities' are highly ranked. These motives have average values above 4, being mostly referred to as 'agree' or 'totally agree'. On the contrary, 'Continuation of family tradition' received low approval, which can be a signal of the relatively small number of family firm take-over possibilities among the students in our sample.

$<$ Table 3 about here $>$

\subsection{Main Components of Motives}

Through the principal component analysis and by making use of the varimax rotation method, Table 3 indicates three significant components or, respectively, factors. The main factors extracted explained a total of $48.36 \%$ of the observed variance, making good conceptual sense. The Kaiser-Meyer-Olkin measure of sampling adequacy is close to 0.7, which is almost classified as 'middling' (Kaiser \& Rice, 1974), guaranteeing reliability of the analysis. Consequently, three factors, which we will discuss now, were the result of applying the principal component analysis:

Factor 1. This factor includes motives associated with 'The current situation in the labour market', 'The chance of higher income' and 'Prestige and social status'. The outstanding characteristic of this factor is to achieve recognition and esteem through the working position and the related income. This is, of course, influenced by adequate job offers and areas of operation. Accordingly, we label this first factor 'Status orientation'.

Factor 2. This factor is composed of the motives 'Working under one's own initiative', 'Realising one's own business or product ideas', 'Making better use of one's own capabilities' and 'Fun when dealing with opportunities and risks'. What shapes this factor is the pursuit of independence and individual fulfilment, which also implies bearing certain risks. Based on this, we call the second factor 'Self-realisation'.

Factor 3. This factor consists of motives associated with 'Being one's own boss', 'Self deciding on working hours and place' as well as 'Continuation of family tradition'. Here, the dominating elements are the strong wish for autonomy and to take matters into one's own hands, to a certain extent influenced by the experiences from the family's business. For this reason, the third factor is named 'Self-determination'.

Based on these insights, we will now proceed to explore the relationship between the students' working preferences and both the motives for career choice (Model 1) as well as their three main components we identified (Model 2).

\subsection{Motives and Career Choice}

Table 4 shows outcomes of the logit model for different career alternatives right after graduation ( $\mathrm{t} 0$ ), and Table 5 illustrates the respective results for the intended career paths five years after completing the studies (t5).

\section{$<$ Tables 4 and 5 about here>}

Students who strive for an employment with a large company directly after graduation highlight motives associated with 'Status orientation' as particularly important. The main drivers within this main component are motives associated with the chance of high income as well as prestige and social status. Furthermore, the preference of working in a medium-sized enterprise five years after graduation is negatively correlated with 'Self-determination', in particular with the wish for being one's own boss. For small sized firms, no statistical robust relationships with the motives or their main components were found at all. In general, both motives and main components we used in our survey are only to a small extent related to the dependent employment alternatives. 
More significant relationships were found when performing the regression analysis for different self-employment modes. Potential firm founders emphasise 'Self-determination' as fundamental directly after graduation, chiefly supported by striving for being one's own boss. Five years later they, again, present the same characteristics within the component 'Self-determination', but then also for 'Self-realisation', predominantly impacted by the desire to realise business or product ideas. This is in line with the insights of our literature review. Respondents who prefer self-employment five years after graduation through businesses take-over or freelancer activities cited motives related to 'Self-determination' relatively more often, again being one's own boss as the key motivational driver. Not surprisingly, those pursuing businesses take-over cited continuing their family tradition relatively more often.

With regard to these insights, our research hypotheses cannot be rejected, at least for the German research context. In the short run, status-oriented motives such as prestige and high income are particularly relevant for students willing to become employed in a large company (H1). Moreover, motives related to self-determination, above all professional autonomy, were found to be inherent in students who want be to self-employed, especially in the long term (H2). Lastly, motives that can be bundled under self-realisation, in particular the wish to realise new business ideas, in the long run are correlated with the students' intention to start a business (H3).

Among the most important significances when controlling for socio-demographic and regional influences, we found that male students prefer working in large companies after graduation and self-employment five years after graduation. Furthermore, older students strive for an employment in the public service or self-employment as freelancer right after graduation and for starting a business five years later. Students of business administration favour mid-sized firms after graduation, and five years later they choose a large company rather than a small one or prefer self-employment through business take-over. There is no significant effect of the participation in entrepreneurship education on any self-employment alternative. Lastly, students from Worms look relatively more out for employment opportunities with large companies, while their counterparts from Jena wish to be employed in the public service directly after graduation. Five years later, also respondents from Jena strive for an employment in a large company, persist in their public service preference and also prefer a business take-over.

\section{Conclusion and Implications}

The present study aims at exploring and differentiating the motives for several types of dependent employment and self-employment. Thereby, we try to contribute to developing a theory about the main drivers for the university students' career choices. Our study reveals several implications for practice, teaching and research. First, we demonstrate that the underlying motives for career choice are interlinked and can be grouped into the main components 'Status orientation', 'Self-realisation' and 'Self-determination'. With this, the variety of reasons for the students' career choice seem to follow a certain taxonomy. Its cognisance can be useful for both educators in their quest to orientate students in career path planning, and for policy-makers and practitioners to understand the graduates' career decisions.

Second, we revealed that motives for career choice and their main categories are highly divergent with respect to the different career alternatives. They are particularly unimportant for individuals who strive for a dependent employment. Solely 'Status orientation' and its underlying motives were found to be relevant for intended career paths in large companies. With regard to self-employment, we found that the motives within this ill-perceived homogeneous group vary noticeably. Interestingly, for the respondents of our sample, the categories 'Self-realisation' and 'Self-determination' are noteworthy to a certain extent when it comes to decide whether or not to enter into self-employment.

In particular, 'Self-determination' was found to be inherent for any type of self-employment, along with the motive of being one's own boss. On the contrary, our findings do not support the common perception that pecuniary remuneration is an important incentive for self-employment. Educators should keep these differences and particularities in mind when building up programmes for sensitising and instructing individuals for specific career alternatives. This applies in particular for the ever-increasing entrepreneurship education, whose influence in our sample was almost insignificant.

Third, we could not detect any specific motives as for working in small firms. However, the availability of qualified staff willing to work in start-up firms is a key condition for growth, as relevant as the 'production' of entrepreneurs themselves. Therefore, it is imperative to inspire students to ponder the option of employment in young firms (Lautenschläger \& Haase, 2010). As a lack of knowledge about the underlying motives for employment in small or new firms remains, we explicitly recommend researchers to continue tackling this fundamental issue in order to explore how these firms can offer incentives to attain the required staff.

Finally, the present study has several limitations. The first limitation concerns the fact that only data from two universities have been analysed. A simple generalisation may be unlikely since idiosyncratic characteristics such as cultural aspects and mentality, industry structure, income level, economic climate, and so on, determine career choice. 
The second limitation has to do with the prospective basis of the study. We asked students about their intentions in some cases years before their career choices will have been made. According to their actual career path and subsequent experiences, their perception may alter in the future. Nevertheless, we hope the findings of our study will inspire other scholars, and the combination of this and future work will surely allow valuable comparisons and insights.

\section{Acknowledgements}

We would like to acknowledge the grants provided by the German Federal Ministry of Economics and Technology and by the European Social Fund (EXIST programme, grant number: 03EXETH008), which enabled us to carry out the research for this article.

\section{References}

Ajzen, I. (1991). The theory of planned behavior. Organizational Behavior and Human Decision Processes, 50(2), 179-211. doi:10.1016/0749-5978(91)90020-T, http://dx.doi.org/10.1016/0749-5978(91)90020-T

Bandura, A., 1977. Social learning theory, Englewood Cliffs (NJ): Prentice-Hall.

Bannock, G. \& Daly, M., 1994. Small Business Statistics, London: Paul Chapman.

Baumol, W. J. (1993). Toward operational models of entrepreneurship. In Ronen, J. (ed.), Entrepreneurship (pp. 29-48). Lexington (MA): Lexington Books.

Belfield, C. R. (1999). The Behaviour of Graduates in the SME Labour Market: Evidence and Perceptions. Small Business Economics, 12(3), 249-259. doi:10.1023/A:1008011303353, http://dx.doi.org/10.1023/A:1008011303353

Birley, S., \& Westhead, P. (1994). A taxonomy of business start-up reasons and their impact on firm growth and size. Journal of Business Venturing, Journal of Business Venturing, 9(1), 7-31. doi:10.1016/0883-9026(94)90024-8, http://dx.doi.org/10.1016/0883-9026(94)90024-8

Blanchflower, D. G., \& Meyer, B. D. (1994). A Longitudinal Analysis of the Young Self-Employed in Australia and the United States. Small Business Economics, Small Business Economics, 6(1), 1-19. doi:10.1007/BF01066108, http://dx.doi.org/10.1007/BF01066108

Bramwell, A., \& Wolfe, D. A. (2008). Universities and regional economic development: The entrepreneurial University of Waterloo. Research Policy, 37(8), 1175-1187. doi:10.1016/j.respol.2008.04.016,

http://dx.doi.org/10.1016/j.respol.2008.04.016

Brockhaus, R. H. (1980). Risk Taking Propensity of Entrepreneurs. The Academy of Management Journal, 23(3), 509-520. doi:10.2307/255515, http://dx.doi.org/10.2307/255515

Carter, N. M., Gartner, W. B., Shaver, K. G., \& Gatewood, E. J. (2003). The career reasons of nascent entrepreneurs.

Journal of Business Venturing, 18(1), 13-39. doi:10.1016/S0883-9026(02)00078-2,

http://dx.doi.org/10.1016/S0883-9026(02)00078-2

Chlosta, S., Klandt, H., \& Johann, T. (2006). German Survey on Collegiate Entrepreneurship. Gründungsneigung deutscher Studierender. Oestrich-Winkel: European Business School (ebs).

Chrisman, J. J., Hynes, T., \& Fraser, S. (1995). Faculty entrepreneurship and economic development: The case of the University of Calgary. Journal of Business Venturing, 10(4), 267-281. doi:10.1016/0883-9026(95)00015-Z,

http://dx.doi.org/10.1016/0883-9026(95)00015-Z

Douglas, E.J. \& Shepherd, D.A. (2002). Self-employment as a Career Choice: Attitudes, Entrepreneurial Intentions, and Utility Maximization. Entrepreneurship Theory and Practice, 26(3), 81-90.

Duchesneau, D.A. \& Gartner, W.B. (1990). A profile of new venture success and failure in an emerging industry.

Journal of Business Venturing, 5(5), 297-312. doi:10.1016/0883-9026(90)90007-G,

http://dx.doi.org/10.1016/0883-9026(90)90007-G

Etzkowitz, H. et al. (2000). The future of the university and the university of the future: evolution of ivory tower to entrepreneurial paradigm. Research Policy, 29(2), 313-330. doi:10.1016/S0048-7333(99)00069-4,

http://dx.doi.org/10.1016/S0048-7333(99)00069-4

Evans, D.S. \& Leighton, L.S. (1989). Some Empirical Aspects of Entrepreneurship. The American Economic Review, 79(3), 519-535.

Falkäng, J. \& Alberti, F. (2000). The assessment of entrepreneurship education. Industry and Higher Education, 14(2), 101-108. doi:10.5367/000000000101294931, http://dx.doi.org/10.5367/000000000101294931

Fueglistaller, U., Klandt, H. \& Halter, F. (2006). International Survey on Collegiate Entrepreneurship 2006, St. Gallen/Oestrich-Winkel: University of St. Gallen (HSG) / European Business School (ebs).

Gatewood, E.J., Shaver, K.G. \& Gartner, W.B. (1995). A longitudinal study of cognitive factors influencing start-up behaviors and success at venture creation. Journal of Business Venturing, 10(5), 371-391. doi:10.1016/0883-9026(95)00035-7, http://dx.doi.org/10.1016/0883-9026(95)00035-7

Gibb, A.A. (1996). Entrepreneurship and Small Business Management: Can We Afford to Neglect Them in the Twenty-First Century Business School? British Journal of Management, 7(4), 309-321. 
doi:10.1111/j.1467-8551.1996.tb00121.x, http://dx.doi.org/10.1111/j.1467-8551.1996.tb00121.x

Golla, S. et al. (2006). Gründungsneigung Studierender - Eine empirische Analyse in Deutschland und der Schweiz. In Achleitner, Ann-Kristin; Klandt, Heinz; Koch, Lambert T.; Voigt, Kai-Ingo (Hrsg.), Jahrbuch Entrepreneurship 2005/06. Gründungsforschung und Gründungsmanagement. Berlin/Heidelberg: Springer, pp. 209-237.

doi:10.1007/3-540-28361-7_10, http://dx.doi.org/10.1007/3-540-28361-7_10

Greene, F. J., \& Saridakis, G. (2008). The Role of Higher Education Skills and Support in Graduate Self-Employment. Studies in Higher Education, 33(6), 653-672. doi:10.1080/03075070802457082, http://dx.doi.org/10.1080/03075070802457082

Hair, J. F., Black, B., \& Babin, B. (2005). Multivariate Data Analysis (6th ed.). New Jersey: Prentice Hall. Hisrich, R. D. (2003). A model for effective entrepreneurship education and research. In K. Walterscheid (ed), Entrepreneurship in Forschung und Lehre: Festschrift für Klaus Anderseck (pp. 241-253). Frankfurt/Main: Peter Lang. Hsu, D. H., Roberts, E. B., \& Eesley, C. E. (2007). Entrepreneurs from technology-based universities: Evidence from MIT. Research Policy, 36(5), 768-788. doi:10.1016/j.respol.2007.03.001, http://dx.doi.org/10.1016/j.respol.2007.03.001 Jacobsen, L.K. (2006). Erfolgsfaktoren bei der Unternehmensgründung. Entrepreneurship in Theorie und Praxis 1. ed., Gabler.

Johannisson, B., Handström, H. \& Rosenberg, J. (1998). University training for entrepreneurship: an action frame of reference. European Journal of Engineering Education, 23(4), 477-496. doi:10.1080/03043799808923526, http://dx.doi.org/10.1080/03043799808923526

Josten, M. et al. (2008). Gründungspotenziale bei Studierenden. Zentrale Ergebnisse der Studierendenbefragung an 37 deutschen Hochschulen, Bonn/Berlin: Bundesministerium für Bildung und Forschung (Hrsg.).

Kaiser, H. F. (1958). The varimax criterion for analytic rotation in factor analysis. Psychometrika, 23(3), 187-200. doi:10.1007/BF02289233, http://dx.doi.org/10.1007/BF02289233

Kaiser, H. F., \& Rice, J. (1974). Little Jiffy, Mark IV. Educational and Psychological Measurement, 34(1), 111-117. doi:10.1177/001316447403400115, http://dx.doi.org/10.1177/001316447403400115

Kalleberg, A. L., \& Buren, M. E. V. (1996). Is Bigger Better? Explaining the Relationship Between Organization Size

and Job Rewards. American Sociological Review, 61(1), 47-66. doi:10.2307/2096406,

http://dx.doi.org/10.2307/2096406

KFW Bankengruppe. (2005). MittelstandsMonitor 2005. Frankfurt/Main: KfW Bankengruppe.

Koh, H. C. (1995). Factors associated with entrepreneurial inclination: An empirical study of business undergraduates in Hong Kong. Journal of Small Business Entrepreneurship, 12(2), 29-41.

Kolvereid, L. (1996). Organizational employment versus self-employment: reasons for career choice intentions. Entrepreneurship Theory and Practice, 20(3), 23-31.

Krueger Jr., N. F., Reilly, M. D., \& Carsrud, A. L. (2000). Competing models of entrepreneurial intentions. Journal of Business Venturing, 15(5-6), 411-432. doi:10.1016/S0883-9026(98)00033-0,

http://dx.doi.org/10.1016/S0883-9026(98)00033-0

Kulicke, M. (1993). Chancen und Risiken junger Technologieunternehmen (1st ed.). Physica-Verlag Heidelberg.

Kuratko, D. F., Hornsby, J. S., \& Naffziger, D. W. (1997). An examination of owner's goals in sustaining entrepreneurship. Journal of Small Business Management, 35(1), 24-33.

Lautenschläger, A., \& Haase, H. (2010). Universities: a hotbed of human resources for new firms? Journal of Small Business and Entrepreneurship, 23 (special issue), 747-759.

Miller, P., \& Mulvey, C. (1996). Unions, Firm Size and Wages. The Economic Record, 72(217), 138-151. doi:10.1111/j.1475-4932.1996.tb00948.x, http://dx.doi.org/10.1111/j.1475-4932.1996.tb00948.x

Nelson, J. I. (1968). Participation and Integration: The Case of the Small Businessman. American Sociological Review, 33(3), 427-438. doi:10.2307/2091916, http://dx.doi.org/10.2307/2091916

Polachek, S. W., \& Siebert, W. S. (1993). The Economics of Earnings. Cambridge: Cambridge University Press.

Roberts, E. B. (1991). Entrepreneurs in High Technology: Lessons from MIT and Beyond. Oxford: Oxford University Press. doi:10.1017/CBO9780511522062, http://dx.doi.org/10.1017/CBO9780511522062

Scheinberg, S., \& MacMillan, I. C. (1988). An 11-country study of motivations to start a business. Frontiers of Entrepreneurship Research, Babson College, Wellesley, MA, 669-687.

Scherer, R. F., Adams, J. S., Carley, S. S., \& Wiebe, F. A. (1989). Role Model Performance Effects on the Development of Entrepreneurial Career Preference. Entrepreneurship Theory and Practice, 13(3), 53-71.

Scherer, R. F., Brodzinski, J. D., \& Wiebe, F. A. (1991). Examining the relationship between personality and entrepreneurial career preference. Entrepreneurship \& Regional Development, 3(2), 195-206. doi:10.1080/08985629100000013, http://dx.doi.org/10.1080/08985629100000013

Scott, M. G., \& Twomey, D. F. (1988). The long-term supply of entrepreneurs: students' career aspirations in relation to entrepreneurship. Journal of Small Business Management, 26(4), 5-13.

Shane, S., Kolvereid, L., \& Westhead, P. (1991). An exploratory examination of the reasons leading to new firm 
formation across country and gender. Journal of Business Venturing, Journal of Business Venturing, 6(6), 431-446. doi:10.1016/0883-9026(91)90029-D, http://dx.doi.org/10.1016/0883-9026(91)90029-D

Shapero, A., \& Sokol, L. (1982). The Social Dimensions of Entrepreneurship. In C. Kent, D. Sexton, and K. H. Vesper (eds.), The Encyclopedia of Entrepreneurship (pp. 72-90). Englewood Cliffs (NJ): Prentice-Hall.

Solomon, G. T., Duffy, S., \& Tarabishy, A. (2002). The State of Entrepreneurship Education in the United States: a national survey and analysis. International Journal of Entrepreneurship Education, 1(1), 65-86.

Steffensen, M., Rogers, E. M., \& Speakman, K. (2000). Spin-offs from research centers at a research university. Journal of Business Venturing, 15(1), 93-111. doi:10.1016/S0883-9026(98)00006-8,

http://dx.doi.org/10.1016/S0883-9026(98)00006-8

Sternberg, R., Brixy, U., \& Hundt, C. (2007). Global Entrepreneurship Monitor. Länderbericht Deutschland 2006. Hannover/Nürnberg: Global Entrepreneurship Research Association.

Tackey, N. D., \& Perryman, S. (1999). Graduates Mean Business: A Study of Graduate Self-Employment and Business Start-Ups. Grantham (UK): Grantham Book Services Ltd.

Van Auken, H., Stephens, P., Fry, F., \& Silva, J. (2006). Role model influences on entrepreneurial intentions: A comparison between USA and Mexico. International Entrepreneurship and Management Journal, 2(3), 325-336. doi:10.1007/s11365-006-0004-1, http://dx.doi.org/10.1007/s11365-006-0004-1

Wagner, J. (1997). Firm Size and Job Quality: A Survey of the Evidence from Germany? Small Business Economics, 9(5), 411-425. doi:10.1023/A:1007961223511, http://dx.doi.org/10.1023/A:1007961223511

Wagner, J. (2004). Are Young and Small Firms Hothouses for Nascent Entrepreneurs? Evidence from German Micro Data. Applied Economics Quarterly, 50(4), 379-391.

Table 1. Motives for Career Choice

\begin{tabular}{|c|c|}
\hline \multicolumn{2}{|c|}{ Motives for career choice } \\
\hline Cognitive factors & Contextual factors \\
\hline Assured position (Lautenschläger \& Haase, 2010) & $\begin{array}{l}\text { Family tradition (Scherer et al., 1989; Duchesneau } \\
\text { \& Gartner, 1990; Scherer et al., 1991; Scott \& } \\
\text { Twomey, 1988; Koh, 1995; Tackey \& Perryman, } \\
\text { 1999; KFW Bankengruppe, 2005; Jacobsen, 2006) }\end{array}$ \\
\hline Being one's own boss (Josten et al., 2008) & $\begin{array}{l}\text { Situation in the labour market (KFW } \\
\text { Bankengruppe, 2005) }\end{array}$ \\
\hline $\begin{array}{l}\text { Financial success and high income (Evans \& Leighton, } \\
\text { 1989; Shane et al., 1991; Carter et al., 2003; Kuratko et } \\
\text { al., 1997; Douglas \& Shepherd, 2002) }\end{array}$ & $\begin{array}{l}\text { Firm size (Bannock \& Daly, 1994; Belfield, 1999; } \\
\text { Golla et al., 2006) }\end{array}$ \\
\hline $\begin{array}{l}\text { Learning, gaining experiences and need for personal } \\
\text { development (Birley \& Westhead, 1994; Gatewood et al., } \\
\text { 1995; Scheinberg \& MacMillan, 1988; Lautenschläger \& } \\
\text { Haase, 2010) }\end{array}$ & \\
\hline $\begin{array}{l}\text { Making better use of one's own capabilities (Josten et al., } \\
\text { 2008) }\end{array}$ & \\
\hline $\begin{array}{l}\text { Need of autonomy and independence (Brockhaus, 1980; } \\
\text { Carter et al., 2003; Van Auken et al., 2006; Kuratko et } \\
\text { al., 1997; Douglas \& Shepherd, 2002) }\end{array}$ & \\
\hline $\begin{array}{l}\text { Realising one's own business or product ideas (Josten et } \\
\text { al., 2008) }\end{array}$ & \\
\hline $\begin{array}{l}\text { Self deciding on working hours and place (Josten et al., } \\
\text { 2008) }\end{array}$ & \\
\hline $\begin{array}{l}\text { Self-realisation (Gatewood et al., 1995; Kolvereid, 1996; } \\
\text { Carter et al., 2003) }\end{array}$ & \\
\hline $\begin{array}{l}\text { Social recognition and status (Shane et al., 1991; Birley } \\
\text { \& Westhead, 1994; Carter et al., 2003; Nelson, 1968; } \\
\text { Scheinberg \& MacMillan, 1988) }\end{array}$ & \\
\hline Taking risks (Koh, 1995; Van Auken et al., 2006) & \\
\hline $\begin{array}{l}\text { Working under one's initiative (Kulicke, 1993; Josten et } \\
\text { al., 2008) }\end{array}$ & \\
\hline
\end{tabular}


Table 2. Descriptive Analysis

\begin{tabular}{|c|c|c|}
\hline \multicolumn{1}{|c|}{ Variables } & Mean & Std. Deviation \\
\hline Career choice at $t_{0}$ & & \\
\hline Employed in a small-size firm & 0.124 & 0.330 \\
\hline Employed in a medium-sized firm & 0.318 & 0.466 \\
\hline Employed in a large company & 0.293 & 0.455 \\
\hline Self-employed as freelancer & 0.025 & 0.156 \\
\hline Self-employed by business take-over & 0.029 & 0.169 \\
\hline Self-employed by starting a business & 0.023 & 0.151 \\
\hline Career choice at $t_{5}$ & & 0.252 \\
\hline Employed in a small-size firm & 0.068 & 0.380 \\
\hline Employed in a medium-sized firm & 0.197 & 0.485 \\
\hline Employed in a large company & 0.378 & 0.286 \\
\hline Self-employed as freelancer & 0.090 & 0.265 \\
\hline Self-employed by business take-over & 0.076 & 0.391 \\
\hline Self-employed by starting a business & 0.188 & \\
\hline Socio-demographic and regional aspects & & 0.497 \\
\hline Gender (0=female, 1=male) & 0.444 & 2.855 \\
\hline Age & 24.10 & 0.479 \\
\hline Course of study (1=business, 0=other) & 0.645 & 0.470 \\
\hline Participation in EE (1=yes, 0=no) & 0.329 & 0.489 \\
\hline Region (1=Jena, 0=Worms) & 0.394 & \\
\hline
\end{tabular}

Table 3. Descriptive Results and Principal Component Analysis for Motives

\begin{tabular}{|c|c|c|c|c|c|}
\hline \multirow[t]{2}{*}{ Variables } & \multicolumn{2}{|c|}{ Descriptive Statistics } & \multicolumn{3}{|c|}{ Components } \\
\hline & Mean & Std. Deviation & Factor 1 & Factor 2 & Factor 3 \\
\hline The current situation in the labour market & 3.540 & 1.031 & 0.6580 & & \\
\hline The chance of higher income & 3.540 & 1.031 & 0.6580 & & \\
\hline Prestige and social status & 3.249 & 1.039 & 0.7080 & & \\
\hline Working under one's own initiative & 4.343 & 0.692 & & 0.6715 & \\
\hline Realising one's own business or product ideas & 3.598 & 0.901 & & 0.5744 & \\
\hline Making better use of one's own capabilities & 4.240 & 0.696 & & 0.6551 & \\
\hline Fun when dealing with opportunities and risks & 3.541 & 0.908 & & 0.5112 & \\
\hline Being one's own boss & 3.154 & 0.981 & & & 0.6441 \\
\hline Self deciding on working hours and place & 3.676 & 0.952 & & & 0.6683 \\
\hline Continuation of family tradition & 2.174 & 1.283 & 0.4062 & & 0.4704 \\
\hline Eigenvalues & & & 2.264 & 1.466 & 1.106 \\
\hline Percentage of explained variance & & & 18.05 & 16.51 & 13.80 \\
\hline Percentage of cumulative variance & & & 18.05 & 34.56 & 48.36 \\
\hline
\end{tabular}




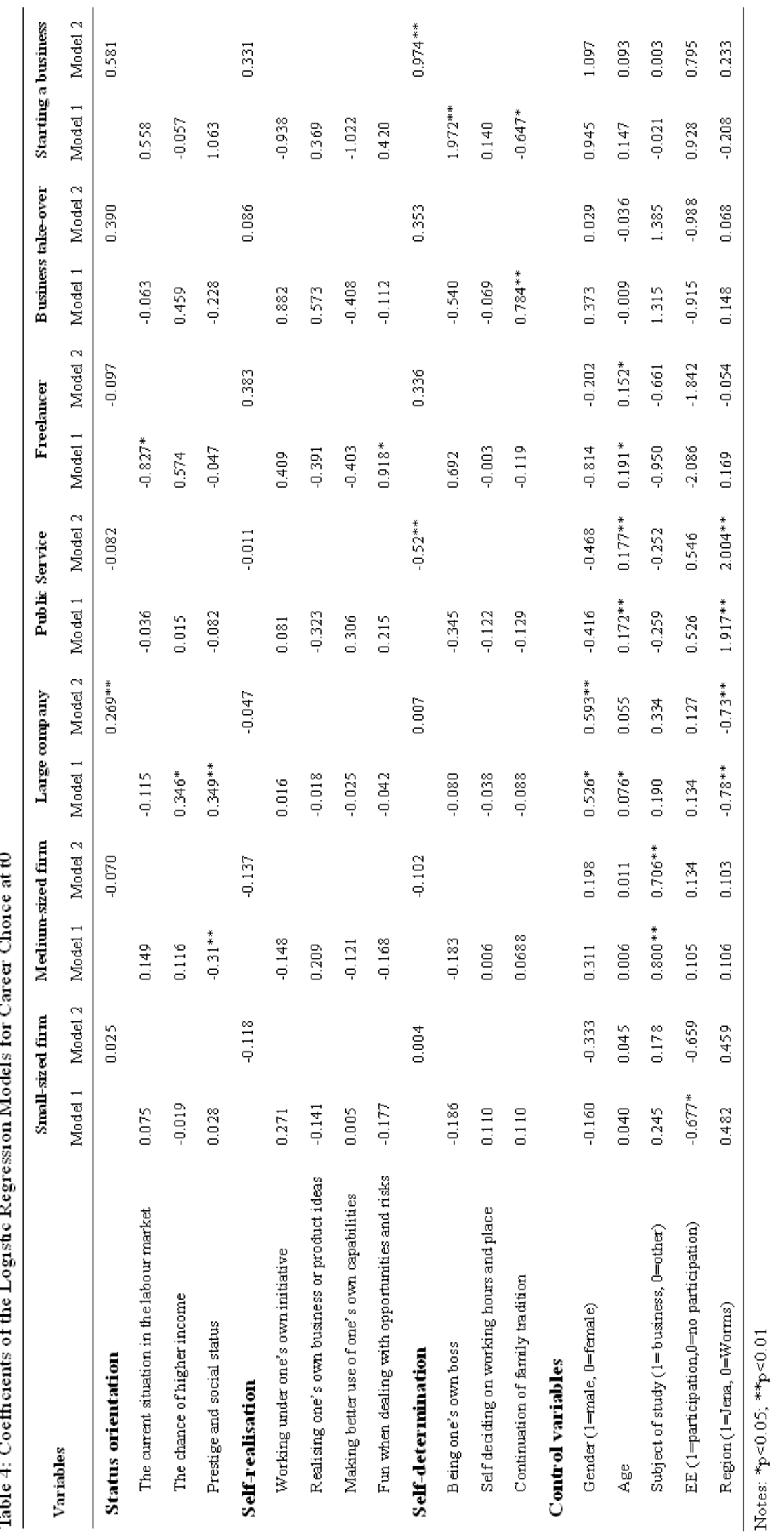




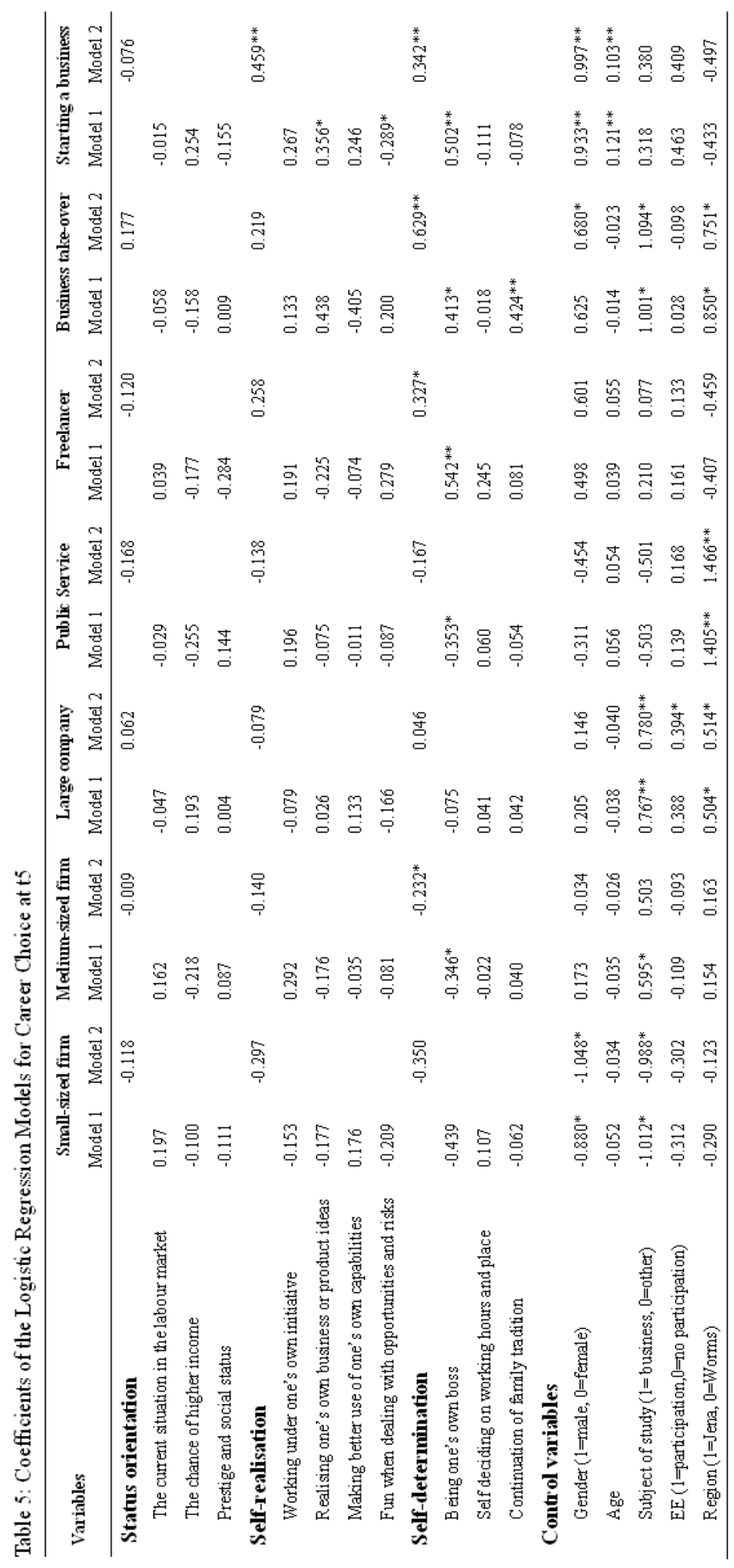

